\title{
Nitrogen-Balance Studies on Rice Diets
}

\author{
By H. CULLUMBINE \\ Department of Physiology and Pharmacology, University of Ceylon, Colombo
}

(Received 16 Yanuary 1950)

During a series of experiments designed to study mineral metabolism on rice diets (Cullumbine, Basnayake, LeMottee \& Wickramanayake, 1950), it was also found possible to estimate the nitrogen content of the food and excreta for the group of twelve subjects and so to determine whether there were any differences in the nitrogen metabolism of subjects when eating diets first high in unpolished rice and then high in polished rice.

\section{METHODS}

The general organization of the experiment was as previously described (Cullumbine et al. 1950). Briefly, twelve male medical students (ages 21-25 years) acted as the subjects. They all lived in a nearby hostel so that it was easy to control their diet and to collect specimens. Each subject ate daily the equivalent of 9 oz. raw rice and this rice supplied $40-50 \%$ of the total calories and $25-30 \%$ of the total protein (Table 1 ). The total protein intake accounted for II-I $5 \%$ of the total calories and half the protein was obtained from meat, fish and dairy products. In addition, $3.5 \mathrm{oz}$. daily of white bread were eaten by each subject. Such a diet is typical of that consumed by the middle-class Ceylonese (Cullumbine, Bibile \& Wickramanayake, 1949). Students were allowed some choice of the actual green vegetables, vegetable fruits (bread-fruit, jackfruit, brinjals, ladies' fingers) and fresh fruit to be eaten. Once the individual choice had been made, the diet was repeated week by week. This freedom enhanced the palatability of the diet to each individual and tended to prevent boredom throughout the long period of observation.

The different varieties of rice were taken as follows.

Weeks $\mathrm{I}-4$ inclusive: 'normal' diet, i.e. a mixture of Ceylon Country rice (lightly milled and parboiled) and Europe no. 2 rice (well milled, polished, raw rice, $47 \%$ extraction rate) in the proportions of $4: 6$.

Weeks $5-7$ inclusive: 'unpolished' rice diet, i.e. Ceylon Country rice.

Weeks 8-10 inclusive: 'polished' rice diet, i.e. Europe no. 2 rice.

Sampling of diet, faeces and urine was done for 7 consecutive days, during each of weeks 2, 4, 7 and 10. The first 2 weeks ( 2 and 4 ) enabled me to determine that each subject was in a maintained nitrogen balance. The subsequent sampling weeks were spaced to allow the subjects time to adjust themselves to the new dietary conditions. The 24 hr. urine output was recorded, 7-day composite specimens were prepared with toluene $(2 \mathrm{ml} . / 100 \mathrm{ml}$.) as preservative and $10 \mathrm{ml} .2 \mathrm{~N}-\mathrm{HCl}$ to prevent loss of nitrogen as ammonia. Portions were taken for analysis of total nitrogen. The faeces, marked with carmine, were also collected under $2 \mathrm{~N}-\mathrm{HCl}$, bulked for each 7-day period and mixed in 
a Waring Blendor with distilled water. Portions were dried and then analysed for total nitrogen. The determinations of total nitrogen in food and excreta were performed by the micro-Kjeldahl technique.

'The subjects maintained a constant weight throughout the experiment.

T'riplicate samples were taken for nitrogen estimations and duplicate samples for other measurements, and the determinations were repeated if good agreement was not obtained.

Table 1. Daily intake and distribution of calories of the experimental subjects and percentage of nitrogen derived from rice

\begin{tabular}{|c|c|c|c|c|c|c|}
\hline \multirow[b]{3}{*}{$\begin{array}{l}\text { Subject } \\
\text { no. }\end{array}$} & \multicolumn{5}{|c|}{ Calorie intake } & \multirow{3}{*}{$\begin{array}{l}\text { Percentage } \\
\text { of total } \\
\text { nitrogen } \\
\text { from rice }\end{array}$} \\
\hline & \multirow[b]{2}{*}{ Total } & \multirow[b]{2}{*}{$\begin{array}{l}\text { From } \\
\text { protein }\end{array}$} & \multicolumn{3}{|c|}{ Percentage distribution } & \\
\hline & & & $\begin{array}{c}\text { From } \\
\text { fat }\end{array}$ & $\begin{array}{c}\text { From } \\
\text { carbohydrate }\end{array}$ & $\begin{array}{l}\text { From } \\
\text { rice }\end{array}$ & \\
\hline I & 2004 & $13 \cdot 6$ & $18 \cdot 0$ & $68 \cdot 4$ & $45 \cdot 0$ & $27 \cdot 8$ \\
\hline 2 & 2229 & II.O & $16 \cdot 6$ & $72 \cdot 4$ & $40 \cdot 3$ & $31 \cdot 0$ \\
\hline 3 & 2161 & $13 \cdot 7$ & $16 \cdot 3$ & $70 \cdot 0$ & $4 r \cdot 6$ & $25 \cdot 6$ \\
\hline 4 & 2115 & $12 \cdot 3$ & $24 \cdot 8$ & $62 \cdot 9$ & $42 \cdot 6$ & $29 \cdot 1$ \\
\hline 5 & 1995 & 15.4 & $22 \cdot 2$ & $62 \cdot 4$ & $45^{\cdot} \mathrm{I}$ & $24 \cdot 6$ \\
\hline 6 & 1806 & $15 \cdot 0$ & $24 \cdot 4$ & $60 \cdot 6$ & $48 \cdot 8$ & $27 \cdot 8$ \\
\hline 7 & $23 \times 3$ & $12 \cdot 8$ & $17 \cdot 5$ & $69 \cdot 7$ & $38 \cdot 9$ & 25.6 \\
\hline 8 & 1834 & $12 \cdot 7$ & 16.7 & $70 \cdot 6$ & $49 \cdot 1$ & $32 \cdot 6$ \\
\hline 9 & 1942 & $140^{\circ}$ & $9 \cdot 3$ & $76 \cdot 7$ & $46 \cdot 3$ & $27 \cdot 8$ \\
\hline 10 & 2049 & $13 \cdot 3$ & 15.8 & 70.9 & $43 \cdot 8$ & $27 \cdot 8$ \\
\hline II & 1835 & 14.8 & $17 \cdot 7$ & $67 \cdot 5$ & $49 \cdot 0$ & $27 \cdot 8$ \\
\hline 12 & 2017 & $15 \cdot 3$ & $20 \cdot 5$ & $64 \cdot 2$ & $44 \cdot 7$ & $24 \cdot 6$ \\
\hline
\end{tabular}

RESULTS

The results are expressed as average daily intakes and excretions of nitrogen and are detailed in Table 2. The figures obtained for the two preliminary sampling periods (weeks 2 and 4 ) were so consistent that only the results for week 4 are given for this diet.

All twelve subjects had a positive nitrogen balance during the 4 preliminary weeks that they were eating a normal diet. The intake of nitrogen on the unpolished rice diet was, in all subjects but no. I, greater with the unpolished rice than with the polished rice diet. This was to be expected since unpolished rice has a slightly higher protein content than polished rice (Platt, 1939). In spite of this, ten of the subjects had a greater nitrogen balance on the polished rice diet than on the unpolished rice. This difference was due to the fact that all subjects excreted more nitrogen in the faeces on the unpolished rice. This indicates that the digestibility of the protein in unpolished rice is poorer than that of the protein in polished rice. Unfortunately, as the experiments were designed to study mainly the mineral metabolism, no control figures are available for the faecal excretion of nitrogen of these subjects when consuming a low-protein or a standardprotein diet so that the 'true' digestibility of the protein in rice cannot be determined from these data. The 'apparent' digestibility $\left(\frac{\text { nitrogen intake }- \text { faecal nitrogen }}{\text { nitrogen intake }} \times 100\right)$ can be calculated and, in all instances, this is greater for polished rice than for unpolished 
Table 2. The daily intake, excretion, and retention of nitrogen from diets containing unpolished and polished rice

\begin{tabular}{|c|c|c|c|c|c|c|c|c|c|}
\hline \multirow[b]{2}{*}{$\begin{array}{c}\text { Subject } \\
\text { no. }\end{array}$} & \multirow[b]{2}{*}{$\begin{array}{c}\text { Weight } \\
\text { (kg.) }\end{array}$} & \multirow[b]{2}{*}{$\begin{array}{l}\text { Height } \\
\text { (cm.) }\end{array}$} & \multirow[b]{2}{*}{ Diet } & \multicolumn{2}{|c|}{ Intake } & \multicolumn{3}{|c|}{ Fxcretion } & \multirow[b]{2}{*}{$\begin{array}{c}\text { Balance } \\
\text { (g.) }\end{array}$} \\
\hline & & & & (g.) & $\begin{array}{c}\text { body- } \\
\text { weight) }\end{array}$ & $\begin{array}{c}\text { Faeces } \\
\text { (g.) }\end{array}$ & $\begin{array}{c}\text { Urine } \\
\text { (g.) }\end{array}$ & $\begin{array}{c}\text { Total } \\
\text { (g.) }\end{array}$ & \\
\hline I & $55^{\circ} \circ$ & 158.5 & $\begin{array}{l}\text { Normal } \\
\text { Unpolished rice } \\
\text { Polished rice }\end{array}$ & $\begin{array}{l}12 \cdot 0 \\
11 \cdot 3 \\
11 \cdot 8\end{array}$ & $\begin{array}{l}0.22 \\
0.21 \\
0.22\end{array}$ & $\begin{array}{l}2 \cdot 8 \\
3 \cdot 1 \\
2 \cdot 5\end{array}$ & $\begin{array}{l}8 \cdot 6 \\
8 \cdot 5 \\
8 \cdot 9\end{array}$ & $\begin{array}{l}\mathrm{II} \cdot 4 \\
\mathrm{II} \cdot 6 \\
\mathrm{II} \cdot 4\end{array}$ & $\begin{array}{l}+0.6 \\
-0.3 \\
+0.4\end{array}$ \\
\hline 2 & $55^{\circ} 0$ & $160 \cdot 5$ & $\begin{array}{l}\text { Normal } \\
\text { Unpolished rice } \\
\text { Polished rice }\end{array}$ & $\begin{array}{r}9 \cdot 7 \\
10 \cdot 3 \\
10 \cdot 2\end{array}$ & $\begin{array}{l}0.18 \\
0.19 \\
0.19\end{array}$ & $\begin{array}{l}1 \cdot 3 \\
2 \cdot 3 \\
1 \cdot 6\end{array}$ & $\begin{array}{l}8 \cdot 0 \\
8 \cdot 2 \\
7 \cdot 8\end{array}$ & $\begin{array}{r}9 \cdot 3 \\
10 \cdot 5 \\
9 \cdot 4\end{array}$ & $\begin{array}{l}+0.4 \\
-0.2 \\
+0.8\end{array}$ \\
\hline 3 & $72 \cdot 5$ & $163 \cdot 0$ & $\begin{array}{l}\text { Normal } \\
\text { Unpolished rice } \\
\text { Polished rice }\end{array}$ & $\begin{array}{l}13 \cdot 1 \\
12 \cdot 8 \\
12 \cdot 6\end{array}$ & $\begin{array}{l}0.18 \\
0.18 \\
0.18\end{array}$ & $\begin{array}{l}1 \cdot 9 \\
1 \cdot 9 \\
1 \cdot 1\end{array}$ & $\begin{array}{l}9 \cdot 8 \\
9 \cdot 4 \\
9 \cdot 1\end{array}$ & $\begin{array}{l}11 \cdot 7 \\
11 \cdot 3 \\
10 \cdot 2\end{array}$ & $\begin{array}{l}+1 \cdot 4 \\
+1 \cdot 5 \\
+2 \cdot 4\end{array}$ \\
\hline 4 & $56 \cdot 5$ & $162 \cdot 0$ & $\begin{array}{l}\text { Normal } \\
\text { Unpolished rice } \\
\text { Polished rice }\end{array}$ & $\begin{array}{l}\text { II. } \\
11 \cdot 3 \\
11 \cdot 0\end{array}$ & $\begin{array}{l}0.20 \\
0.20 \\
0.19\end{array}$ & $\begin{array}{l}2 \cdot 8 \\
3 \cdot 1 \\
2 \cdot 4\end{array}$ & $\begin{array}{l}8 \cdot 0 \\
7 \cdot 8 \\
7 \cdot 9\end{array}$ & $\begin{array}{l}10.8 \\
10.9 \\
10.3\end{array}$ & $\begin{array}{l}+0.3 \\
+0.4 \\
+0.7\end{array}$ \\
\hline 5 & $61 \cdot 5$ & $180 \cdot 0$ & $\begin{array}{l}\text { Normal } \\
\text { Unpolished rice } \\
\text { Polished rice }\end{array}$ & $\begin{array}{l}13 \cdot 0 \\
13.5 \\
13 \cdot 1\end{array}$ & $\begin{array}{l}0.21 \\
0.22 \\
0.21\end{array}$ & $\begin{array}{l}2 \cdot 3 \\
2 \cdot 6 \\
1 \cdot 7\end{array}$ & $\begin{array}{r}9.1 \\
9.7 \\
10.0\end{array}$ & $\begin{array}{l}11 \cdot 4 \\
12 \cdot 3 \\
11 \cdot 7\end{array}$ & $\begin{array}{l}+x \cdot 6 \\
+1 \cdot 2 \\
+1 \cdot 4\end{array}$ \\
\hline 6 & $51 \cdot 5$ & 166.0 & $\begin{array}{l}\text { Normal } \\
\text { Unpolished rice } \\
\text { Polished rice }\end{array}$ & $\begin{array}{l}11 \cdot 4 \\
11 \cdot 9 \\
11 \cdot 9\end{array}$ & $\begin{array}{l}0.22 \\
0.23 \\
0.23\end{array}$ & $\begin{array}{l}1 \cdot 4 \\
1 \cdot 8 \\
1 \cdot 3\end{array}$ & $\begin{array}{l}7 \cdot 6 \\
7 \cdot 4 \\
7 \cdot 4\end{array}$ & $\begin{array}{l}9 \cdot 0 \\
9 \cdot 2 \\
8 \cdot 7\end{array}$ & $\begin{array}{l}+2 \cdot 4 \\
+2 \cdot 7 \\
+3 \cdot 2\end{array}$ \\
\hline 7 & $50 \cdot 0$ & 158.5 & $\begin{array}{l}\text { Normal } \\
\text { Unpolished rice } \\
\text { Polished rice }\end{array}$ & $\begin{array}{l}12 \cdot 4 \\
12 \cdot 8 \\
12 \cdot 7\end{array}$ & $\begin{array}{l}0.25 \\
0.25 \\
0.25\end{array}$ & $\begin{array}{l}3 \cdot 7 \\
3 \cdot 9 \\
3 \cdot 1\end{array}$ & $\begin{array}{l}7 \cdot 7 \\
7 \cdot 4 \\
7 \cdot 9\end{array}$ & $\begin{array}{l}\mathrm{XI} \cdot 4 \\
11 \cdot 2 \\
11 \cdot 0\end{array}$ & $\begin{array}{l}+1 \cdot 0 \\
+1 \cdot 6 \\
+1 \cdot 7\end{array}$ \\
\hline 8 & $46 \cdot 5$ & $157^{\circ} 0$ & $\begin{array}{l}\text { Normal } \\
\text { Unpolished rice } \\
\text { Polished rice }\end{array}$ & $\begin{array}{l}10.0 \\
10.6 \\
10.0\end{array}$ & $\begin{array}{l}0.22 \\
0.23 \\
0.22\end{array}$ & $\begin{array}{l}2 \cdot 3 \\
2 \cdot 5 \\
1.8\end{array}$ & $\begin{array}{l}6 \cdot 1 \\
6 \cdot 4 \\
6 \cdot 5\end{array}$ & $\begin{array}{l}8 \cdot 4 \\
8 \cdot 9 \\
8 \cdot 3\end{array}$ & $\begin{array}{l}+\mathrm{r} \cdot 6 \\
+\mathrm{I} \cdot 7 \\
+\mathrm{I} \cdot 7\end{array}$ \\
\hline 9 & $53 \cdot 0$ & $158 \cdot 5$ & $\begin{array}{l}\text { Normal } \\
\text { Unpolished rice } \\
\text { Polished rice }\end{array}$ & $\begin{array}{l}11 \cdot 6 \\
11 \cdot 1 \\
10 \cdot 9\end{array}$ & $\begin{array}{l}0.22 \\
0.21 \\
0.21\end{array}$ & $\begin{array}{l}2 \cdot 6 \\
2 \cdot 9 \\
2 \cdot 0\end{array}$ & $\begin{array}{l}7 \cdot 7 \\
7 \cdot 4 \\
7 \cdot 2\end{array}$ & $\begin{array}{r}10 \cdot 3 \\
10 \cdot 3 \\
9 \cdot 2\end{array}$ & $\begin{array}{l}+1.3 \\
+0.8 \\
+1.7\end{array}$ \\
\hline 10 & $58 \cdot 5$ & I 54.5 & $\begin{array}{l}\text { Normal } \\
\text { Unpolished rice } \\
\text { Polished rice }\end{array}$ & $\begin{array}{l}11 \cdot 4 \\
11 \cdot 6 \\
11 \cdot 5\end{array}$ & $\begin{array}{l}0.20 \\
0.20 \\
0.20\end{array}$ & $\begin{array}{l}2 \cdot 4 \\
3 \cdot 0 \\
1 \cdot 5\end{array}$ & $\begin{array}{l}7 \cdot 7 \\
7 \cdot 6 \\
8 \cdot 3\end{array}$ & $\begin{array}{r}10 \cdot 1 \\
10 \cdot 6 \\
9 \cdot 8\end{array}$ & $\begin{array}{l}+I \cdot 3 \\
+r \cdot 0 \\
+1 \cdot 7\end{array}$ \\
\hline II & $64^{\circ} \circ$ & $163 \cdot 0$ & $\begin{array}{l}\text { Normal } \\
\text { Unpolished rice } \\
\text { Polished rice }\end{array}$ & $\begin{array}{l}12 \cdot 0 \\
12 \cdot 0 \\
11 \cdot 4\end{array}$ & $\begin{array}{l}0.19 \\
0.19 \\
0.18\end{array}$ & $\begin{array}{l}2 \cdot 6 \\
3 \cdot 1 \\
1 \cdot 5\end{array}$ & $\begin{array}{l}7 \cdot 9 \\
7 \cdot 5 \\
8 \cdot 0\end{array}$ & $\begin{array}{r}10.5 \\
10.6 \\
9.5\end{array}$ & $\begin{array}{l}+1 \cdot 5 \\
+1 \cdot 4 \\
+x \cdot 9\end{array}$ \\
\hline 12 & $64 \cdot 5$ & 160.0 & $\begin{array}{l}\text { Normal } \\
\text { Unpolished rice } \\
\text { Polished rice }\end{array}$ & $\begin{array}{l}12 \cdot 9 \\
13 \cdot 0 \\
12 \cdot 3\end{array}$ & $\begin{array}{l}0.20 \\
0.20 \\
0.19\end{array}$ & $\begin{array}{l}2 \cdot 1 \\
2 \cdot 1 \\
1 \cdot 6\end{array}$ & $\begin{array}{l}10.5 \\
10.6 \\
10.6\end{array}$ & $\begin{array}{l}12 \cdot 6 \\
12 \cdot 7 \\
12 \cdot 2\end{array}$ & $\begin{array}{l}+0.3 \\
+0.3 \\
+0.1\end{array}$ \\
\hline
\end{tabular}

rice (Table 3). The difference between the faecal excretion of nitrogen on the two types of diet is not necessarily all accounted for by unabsorbed food nitrogen. That is, it cannot be assumed that the endogenous faecal nitrogen was constant on the two diets. McCance \& Widdowson (1947) and Dawbarn (1949) have indicated that the faecal nitrogen increases as the bulk of the faeces is increased by indigestible residues. The subjects had bulkier faeces when eating unpolished rice diet than when consuming polished rice and this increased bulk may have stimulated increased secretions from the lower bowel. The average daily weight of faeces was $319 \mathrm{~g}$. moist and $72 \mathrm{~g}$. dry for the unpolished rice diet, and $153 \mathrm{~g}$. moist and $27 \mathrm{~g}$. dry for the polished rice diet 
Table 3. The apparent protein digestibility of, and the nitrogen absorption and retention from, diets containing unpolished and polished rice

\begin{tabular}{|c|c|c|c|c|}
\hline $\begin{array}{c}\text { Subject } \\
\text { no. }\end{array}$ & Diet & $\begin{array}{l}\text { Apparent } \\
\text { protein } \\
\text { digestibility } \\
(\%)\end{array}$ & $\begin{array}{c}\text { Nitrogen } \\
\text { absorption } \\
\text { (mg./day) }\end{array}$ & $\begin{array}{c}\text { Nitrogen } \\
\text { retention } \\
(\%)\end{array}$ \\
\hline I & $\begin{array}{l}\text { Unpolished rice } \\
\text { Polished rice }\end{array}$ & $\begin{array}{l}72 \cdot 3 \\
78 \cdot 7\end{array}$ & $\begin{array}{l}8,141 \\
9,309\end{array}$ & $\overline{4.7}$ \\
\hline 2 & $\begin{array}{l}\text { Unpolished rice } \\
\text { Polished rice }\end{array}$ & $\begin{array}{l}77 \cdot 9 \\
84 \cdot x\end{array}$ & $\begin{array}{l}8,008 \\
8,644\end{array}$ & $\overline{9 \cdot 6}$ \\
\hline 3 & $\begin{array}{l}\text { Unpolished rice } \\
\text { Polished rice }\end{array}$ & $\begin{array}{l}84 \cdot 7 \\
91 \cdot 1\end{array}$ & $\begin{array}{l}10,870 \\
11,502\end{array}$ & $\begin{array}{l}13.7 \\
20.6\end{array}$ \\
\hline 4 & $\begin{array}{l}\text { Unpolished rice } \\
\text { Polished rice }\end{array}$ & $\begin{array}{l}73^{\circ} \circ \\
77^{\circ} 9\end{array}$ & $\begin{array}{l}8,269 \\
8,585\end{array}$ & $\begin{array}{l}5 \cdot 2 \\
7 \cdot 7\end{array}$ \\
\hline 5 & $\begin{array}{l}\text { Unpolished rice } \\
\text { Polished rice }\end{array}$ & $\begin{array}{l}80 \cdot 4 \\
87 \cdot 0\end{array}$ & $\begin{array}{l}10,903 \\
11,35^{8}\end{array}$ & $\begin{array}{l}x \times \cdot 3 \\
12 \cdot 2\end{array}$ \\
\hline 6 & $\begin{array}{l}\text { Unpolished rice } \\
\text { Polished rice }\end{array}$ & $\begin{array}{l}84 \cdot 7 \\
88 \cdot 4\end{array}$ & $\begin{array}{l}10,106 \\
10,5^{87}\end{array}$ & $\begin{array}{l}27 \cdot 3 \\
29 \cdot 8\end{array}$ \\
\hline 7 & $\begin{array}{l}\text { Unpolished rice } \\
\text { Polished rice }\end{array}$ & $\begin{array}{l}70 \cdot 0 \\
75 \cdot 2\end{array}$ & $\begin{array}{l}8,935 \\
9,548\end{array}$ & $\begin{array}{l}\text { I6.7 } \\
\text { I } 7 \cdot 4\end{array}$ \\
\hline 8 & $\begin{array}{l}\text { Unpolished rice } \\
\text { Polished rice }\end{array}$ & $\begin{array}{l}76 \cdot 2 \\
81 \cdot 2\end{array}$ & $\begin{array}{l}8,107 \\
8,158\end{array}$ & $\begin{array}{l}20 \cdot 7 \\
20 \cdot 2\end{array}$ \\
\hline 9 & $\begin{array}{l}\text { Unpolished rice } \\
\text { Polished rice }\end{array}$ & $\begin{array}{l}74 \cdot 3 \\
8 I \cdot 4\end{array}$ & $\begin{array}{l}8,267 \\
8,910\end{array}$ & $\begin{array}{l}10 \cdot 2 \\
18 \cdot 8\end{array}$ \\
\hline 10 & $\begin{array}{l}\text { Unpolished rice } \\
\text { Polished rice }\end{array}$ & $\begin{array}{l}73 \cdot 8 \\
87 \cdot 2\end{array}$ & $\begin{array}{r}8,598 \\
10,067\end{array}$ & $\begin{array}{l}11 \cdot 8 \\
17 \cdot 3\end{array}$ \\
\hline II & $\begin{array}{l}\text { Unpolished rice } \\
\text { Polished rice }\end{array}$ & $\begin{array}{l}74 \cdot 5 \\
87 \cdot 1\end{array}$ & $\begin{array}{l}8,917 \\
9,956\end{array}$ & $\begin{array}{l}15 \cdot 8 \\
19.4\end{array}$ \\
\hline 12 & $\begin{array}{l}\text { Unpolished rice } \\
\text { Polished rice }\end{array}$ & $\begin{array}{l}83 \cdot 4 \\
87.0\end{array}$ & $\begin{array}{l}10,834 \\
10,689\end{array}$ & $\begin{array}{l}2.5 \\
0.3\end{array}$ \\
\hline
\end{tabular}

The overall figures show, however, that a greater proportion of the protein was available to the body from polished than from unpolished rice. Not only was the proportion greater but the actual amount of nitrogen available (or 'absorbed') was also greater with the polished rice (Table 3).

The nutritive value of the proteins of rice also depends upon the efficiency with which they can promote growth in the young or maintain nitrogen equilibrium in the adult. The present data do not lend themselves to calculation of the biological values of the proteins in the two types of rice since there was no control diet but, as stated, ten of the subjects had a greater nitrogen balance on the polished rice diet. 'The nitrogen retention $\left(\frac{\text { absorbed nitrogen }- \text { urinary nitrogen }}{\text { absorbed nitrogen }} \times 100\right)$ was also greater with polished rice in ten of the subjects so that it is probable that the biological value of the protein from polished rice is greater than that from unpolished rice.

\section{DISCUSSION}

The digestibility of the nitrogen of wheat flour decreases with increasing degree of extraction (Krebs \& Mellanby, 1942; Murlin, Marshall \& Kochakian, 1941; McCance \& Widdowson, 1947) and my results with highly milled and lightly milled rices agree with those findings for wheat. 
The biological value of the protein of wheat flour, on the other hand, increases with the degree of extraction of the flour (Mitchell \& Carman, 1924, 1926; Fixsen \& Jackson, 1932; Chick, Boas-Fixsen, Hutchinson \& Jackson, 1935; Murlin et al. 194I; Henry \& Kon, 1945). The results reported here indicate that the biological value may be greater for the protein of polished rice than for that of unpolished rice. This is no more than an indication. The number of subjects is too small and the variability between them too large to warrant statistical analysis and, perhaps, a larger-scale experiment would indicate no difference in the apparent biological values. In addition, polishedrice protein cannot contain any amino-acids not present in the protein of unpolished rice, though, it is possible that with unpolished rice there may be less complete digestion of the rice proteins and/or increased faecal excretion of certain amino-acids. (Platt, 1936).

The following difference must be considered between the rice experiments reported here and the wheat-flour experiments performed, in many instances, with rather artificial diets. The apparent protein requirement depends upon the energy intake and the best values are obtained when the protein contribution to the total calorie value of the diet is at a minimum (Dawbarn, 1949). Therefore, many of the wheat-flour experiments reported in the literature were done with diets with a relatively low protein content and with the wheat flour contributing the bulk of the protein. Dietary studies indicate that people in most parts of the world obtain 10-15\% of their calories from protein sources (see, for example, Widdowson, 1936; Widdowson \& McCance, 1936; Cullumbine, 1949). The rice diets used in the present experiments derived I I-15\% of their calorific value from protein and the amount of rice consumed daily was equivalent to that eaten by the average middle-class Ceylonese (Cullumbine et al. 1949).

The results reported here show that it is easier to maintain a nitrogen balance on a diet of polished rice than on a diet of unpolished rice and agree substantially with the findings of Saiki (1930), who also reported that the digestibility of the total nitrogen of unpolished rice was less than that of the nitrogen of polished rice $(75 \%$ compared with $86 \%$ ).

\section{SUMMARY}

1. Nitrogen-balance studies were made on twelve male Ceylonese medical students. Each student consumed daily in a mixed diet $9 \mathrm{oz}$. rice, and the type of rice was varied.

2. The 'apparent' digestibility of the rice proteins was greater for polished rice than for unpolished rice.

3. It is concluded that it is easier to maintain a nitrogen balance on a polished rice diet than on an unpolished rice diet.

\section{REFERENCES}

Chick, H., Boas-Fixsen, M. A., Hutchinson, J. C. D. \& Jackson, H. M. (1935). Biochem. Y. 29, 1712. Cullumbine, H. (1949). Ceylon Y. med. Sci. 6, 213.

Cullumbine, H., Basnayake, V., LeMottee, J., Wickramanayake, T. W. (1950). Brit. f. Nutrit. 4, xor. Cullumbine, H., Bibile, S. W., \& Wickramanayake, T. W. (1949). Ceylon $\mathcal{~ f . ~ m e d . ~ S c i . ~ 6 , ~} 253$.

Dawbarn, M. C. (1949). Nutr. Abstr. Rev. 18, 691.

Fixsen, M. A. \& Jackson, H. M. (1932). Biochem. F. 26, 1923.

Henry, K. M. \& Kon, S. K. (1945). J. Soc. chem. Ind., Lond., 64, 227.

Krebs, H. A. \& Mellanby, K. (1942). Lancet, 242, 319. 
McCance, R. A. \& Widdowson, E. M. (1947). I. Hyg., Camb., 45, 59.

Mitchell, H. H. \& Carman, G. G. (1924). F. biol. Chem. 60, 613.

Mitchell, H. H. \& Carman, G. G. (1926). F. biol. Chem. 68, 183.

Murlin, J. R., Marshall, M. E. \& Kochakian, C. D. (194I). F. Nutrit. 22, 573.

Platt, B. S. (1936). Chin. med. J. 50, 140.

Platt, B. S. (1939). Nutrition in the Colonial Empire. London: H. M. Stationery Office.

Saiki, T. (1930). My Principles of Nutrition. Tokyo.

Widdowson, E. M. (1936). F. Hyg., Camb., 36, 269.

Widdowson, E. M. \& McCance, R. A. (1936). J. Hyg., Camb., 36, I3.

\title{
A Comparison of Acid and Enzymic Extraction of Nicotinic Acid from Foodstuffs
}

\author{
By KAMALA SOHONIE AND L. C. MISRA \\ Institute of Science, Bombay, India
}

(Received 25 Yanuary 1950)

The procedure commonly employed for the extraction of nicotinic acid from foodstuffs involves the use of either acid or alkali (Swaminathan, 1938-9, 1942a-c, I944; Harris \& Raymond, 1939; Bandier \& Hald, 1939; Melnick \& Field, 1940a; Kodicek, $1940 a, b)$. This procedure is so drastic that highly coloured extracts, especially with materials of plant origin, are often obtained, and this necessitates separate blank estimations. Further, the manner of evaluating the blank has been shown by Melnick $\&$ Field $(1940 a, b)$ to influence the nicotinic-acid values. Extraction of nicotinic acid from biological materials has been achieved comparatively recently by the use of enzymes such as takadiastase and pepsin (Cheldelin \& Williams, 1942) or an enzyme preparation from the intestinal mucosa of the pig (Bhagvat, 1943). The last preparation contains a large array of enzymes that will extract and liberate nicotinic acid from biological combination. Further, extraction of nicotinic acid from foodstuffs by the extract of pig's mucosa yields colourless, or only slightly coloured, extracts, thereby completely eliminating the need for blanks. The present investigation was undertaken to compare the nicotinic-acid contents of foodstuffs determined after their extraction with $2 \mathrm{~N}-\mathrm{HCl}$ or with an enzyme preparation from the intestinal mucosa of the pig.

\section{EXPERIMENTAL}

Preparation of the enzyme. The intestinal mucosa of the pig was used since it is known to contain a large and varied array of enzymes and is easily obtainable. To a thick viscous suspension of the mucosa an equal volume of $1.0 \%$ saline was added and the mixture was centrifuged. The supernatant liquid was discarded, the residue was suspended in an equal volume of $1.0 \%$ saline and preserved in the ice-box under toluene. The activity of the preparation, which contained proteases, phosphatases, nucleotidases and other enzymes, was found to keep for months. No attempt was made to purify the preparation further, since the object was merely to liberate and extract 